\title{
Acute and sub-chronic toxicity studies of Dichaetanthera africana (Hook. F.) Jacq. Fel. (Melastomataceae) stem bark ethanol extract
}

\author{
Aristide Laurel Mokale Kognou ${ }^{1,2,3}$, Armelle Deutou Tchamgoue ${ }^{2}$, Lauve Rachel Yamthe Tchokouaha ${ }^{2}$, Dominic Ngima \\ Nthenge-Ngumbau ${ }^{4}$, Patrick Valere Tsouh Fokou ${ }^{5}$, Alembert Tiabou Tchinda ${ }^{2}$, Gabriel Agbor Agbor ${ }^{2}$, Rebecca Madeleine \\ Ebelle Etame ${ }^{1}$, Raymond Simplice Mouokeu ${ }^{6}$, Cecile Enguehard Gueiffier ${ }^{7}$, Rajesh Singh Pawar $^{3}$, Albert Sone Mouelle ${ }^{8}$, \\ Rosalie Annie Ngono Ngane ${ }^{1^{*}}$ \\ ${ }^{1}$ Laboratory of Biochemistry, Faculty of Science, University of Douala, P.O. Box 24157, Douala, Cameroon. \\ ${ }^{2}$ Centre for Research on Medicinal Plants and Traditional Medicine, Institute of Medical Research and Medicinal Plants Studies, Ministry of Scientific \\ Research and Innovation, P.O. Box 13033, Yaoundé, Cameroon. \\ ${ }^{3}$ Laboratory of Pharmacognosy, Phytochemistry and Ethnopharmacology, Faculty of Pharmacy, VNS Group of Institutions, VNS Campus, Vidya Vihar, \\ Neelbud - 462044, Bhopal, India. \\ ${ }^{4}$ CSIR-Indian Institute of Chemical Biology, Laboratory of Clinical \& Experimental Neurosciences, Cell Biology \& Physiology Division, 4, Raja S.C. \\ Mullick Road, Kolkata - 700032, India. \\ ${ }^{5}$ Antimicrobial and Biocontrol Agents Unit, University of Yaoundé 1, P.O. Box 812, Yaoundé, Cameroon. \\ ${ }^{6}$ Institute of Fisheries and Aquatic Sciences, University of Douala, P.O. Box 2701, Douala, Cameroon. \\ ${ }^{7}$ Laboratory of Pharmacognosy, Francois-Rabelais University of Tours, 31 Avenue Monge, 37200 Tours, France. \\ ${ }^{8}$ Department of Clinical Sciences, Faculty of Medicine and Pharmaceutical Sciences, University of Douala, P.O. Box 2701, Douala, Cameroon.
}

\begin{tabular}{|c|c|}
\hline ARTICLE INFO & ABSTRACT \\
\hline Article history: & \multirow{5}{*}{$\begin{array}{l}\text { The safety of the ethanol stem bark extract of Dichaetanthera africana (DABE) was evaluated. A single oral dose } \\
\text { of } 1000 \text { and } 2000 \mathrm{mg} / \mathrm{kg} \text { bw was administered to the rats in the acute toxicity study and the animals observed for } 7 \\
\text { days. The crude extract was given by daily oral administration of } 250-1000 \mathrm{mg} / \mathrm{kg} \text { bw for } 28 \text { and } 90 \text { days respectively } \\
\text { in the sub-chronic toxicity test. Body weight, rectal temperature, food and water consumptions were recorded } \\
\text { weekly. Hematological and biochemical parameters and relative organ weights (liver, kidney, heart, and spleen) were } \\
\text { determined at the end of the } 28 \text { and } 90 \text {-day administration. Histopathological examination of the liver and kidney of } \\
\text { rats was done. No adverse effects or mortality were observed throughout the period of the acute toxicity experiment } \\
\left(\mathrm{LD}_{50}>2000 \mathrm{mg} / \mathrm{kg} \text { ). DABE did not produce any mortality and there were no significant differences between groups }\right. \\
\text { in daily oral administration for } 28 \text { days. For } 90 \text { days, DABE caused behavior adverse effects at the dose of } 1000 \mathrm{mg} / \\
\mathrm{kg} \text { bw. DABE resulted in significant changes in biochemical parameters at the dose of } 500 \text { and } 1000 \mathrm{mg} / \mathrm{kg} \text { bw. Liver } \\
\text { histopathology revealed morphological alteration at these doses. The results suggested that DABE is relatively non- } \\
\text { toxic in daily oral administration for } 28 \text { days. However, it becomes toxic for } 90 \text { consecutive days at the doses of } 500 \\
\text { and } 1000 \mathrm{mg} / \mathrm{kg} \text { bw. }\end{array}$} \\
\hline Received on: 13/03/2018 & \\
\hline Accepted on: 18/05/2018 & \\
\hline Available online: $29 / 06 / 2018$ & \\
\hline $\begin{array}{l}\text { Key words: } \\
\text { Dichaetanthera africana, } \\
\text { Melastomataceae, Ethanol } \\
\text { stem bark extract, Oral acute } \\
\text { toxicity, Oral subchronic } \\
\text { toxicity. }\end{array}$ & \\
\hline
\end{tabular}

\section{INTRODUCTION}

Medicinal plants (crude extract, pure compound or derivative) are an unlimited source for the discovery of new medicines. Most of the natural products used in traditional medicine have solid scientific evidence regarding their biological

\footnotetext{
*Corresponding Author

Rosalie Annie Ngono Ngane, Laboratory of Biochemistry, Faculty of Science, University of Douala, P.O. Box 24157, Douala, Cameroon. E-mail:angono@yahoo.com
}

activities (Ochoa et al., 2014; Musila et al., 2017; Tang et al., 2017). However, little information or evidence is available on the possible toxicity of medicinal plants to the consumers (Tang et $a l ., 2017)$. Regarding the discovery and development of drugs, the concerns of health authorities, the pharmaceutical industry and patients must be taken into consideration (Musila et al., 2017). The prompt access to safe and efficient medicines, as well as animal welfare, are of primary interest to the general public, patients, and consumers. Plants used in traditional medicine could be expected to have low side effects due to their long-term use by local 
populations. Nonetheless, the surveys have indicated that many medicinal plants applied in traditional medicine showed adverse effects (Ochoa et al., 2014). Therefore, the traditional use of any plant for medicinal purposes does not guarantee the safety of this plant. Thus, concerns remain about the potential toxic effects of the short-term and long-term use of the medicinal plants. The data from toxicity studies on medicinal plants or other derivatives must be obtained in order to establish their safety for humans essential for the development of pharmaceutical products. (Etame et al., 2017). Therefore, the toxicological study of any medicinal plant extract intended to be used in animals or humans is crucial for the assessment of its potential toxic effects. Dichaetanthera africana is a tree of 9 to $15 \mathrm{~m}$ high, found in riverine woodland from Sierra Leone to Congo and Angola (Pauwels, 1993). The different parts of this plant are medicinally used in Cameroon, Gabon, Sierra Leone, Ivory Coast and Nigeria against coughs, chest pain and fatigue (Burkill, 1997; Fonge et al., 2012). Previous studies on this plant revealed antioxidant, analgesic, antipyretic and anti-inflammatory properties and bioavailability profile of ethanol extract of the stem bark (Mokale et al., 2017a; Mokale et al., 2017b). Akoué et al. (2013) showed that the ethanol, hydroalcoholic and aqueous extracts of the branches of Sakersia africana, an isotype of Dichaetanthera africana, had high total phenol content and good antiradical activity. However, no toxicological study of this extract has been performed. The present study designed to evaluate the toxicity of the ethanol extract from the stem bark of Dichaetanthera africana.

\section{MATERIALS AND METHODS}

\section{Collection of plant material}

The stem bark of $D$. africana was collected from the Littoral Region of Cameroon (Babimbi II). The identification of the plant was done at the National Herbarium of Cameroon, where the sample was identified from that registered under the number 7157/SRFK.

\section{Preparation of crude extract}

The stem bark of $D$. africana $(2 \mathrm{~kg})$ was air-dried and powdered and then was macerated at room temperature in ethanol $(5 \mathrm{~L}, 72 \mathrm{~h}$ ) and then evaporated using a rotary evaporator (Büchi R200) to obtain a crude extract (76.3 g).

\section{Experimental animals}

Nulliparous and non-pregnant Wistar rats (140-200 g) were used and placed in wire mesh plastic cages under normal laboratory conditions. Animals were received a daily food and water ad libitum. This work was done according to the Committee for the Purpose of Control and Supervision of Experiments on Animals (CPCSEA). This guideline has been issued by the Ministry of Environment and Forests, Government of India. This study was approved by the Institutional Animal Ethics Committee (Registration No. 778/PO/a/03/CPCSEA; 03.09.).

\section{Acute oral toxicity}

The acute toxicity test was performed using the OECD guidelines for acute toxicity (2001). Animals were divided into 3 groups of 6 animals each. The experimental rats were deprived of food for $15 \mathrm{~h}$ and then they were weighed before the administration of the extract. The control group was orally administered water (10 $\mathrm{mL} / \mathrm{kg} \mathrm{bw}$ ) while test groups received extract at the doses of 1000 and $2000 \mathrm{mg} / \mathrm{kg}$ bw. Animals were observed for toxic manifestations (reduction in locomotion, aggressiveness, reaction to stimuli, social interactions and aspect of feces) for the next $5 \mathrm{~h}$ and then rats were observed daily for signs of morbidity and mortality for 7 days. Rectal temperature and body weight of the animals during the first 5 hours and once every three days were noticed.

\section{Sub-acute and sub-chronic oral toxicity}

Twenty-four albino rats were used for each experiment. Animals were randomly divided into four groups of 6 rats each. The extract was given by the daily oral administration for 28 and 90 days to the test groups at the different doses (250, 500 and 1000 $\mathrm{mg} / \mathrm{kg}$ ). Control group received only distilled water (OECD, 1998; OECD, 2008). The animals were observed for signs of toxicity and mortality throughout the experimental period. The body weight, rectal temperature, water and food consumptions were recorded weekly. At the end of each experiment, the animals, fasted for 12 $\mathrm{h}$, were sacrificed by decapitation under anesthesia (diethyl ether). Blood was collected by cardiac puncture into two EDTA tubes. The first tube was used for hematological parameters determination and in the second tube 2, plasma was separated by centrifugation for biochemical analysis. The organs (kidneys, liver, heart, and spleen) were weighted. Kidney and liver samples of each group were preserved in 10\% formalin for histopathological examination.

\section{Blood analysis}

Hematological parameters such as white blood cell (WBC) count, red blood cell (RBC) count, platelet (PLT) count, hematocrit (HCT), hemoglobin (HGB), mean corpuscular volume $(\mathrm{MCV})$, mean cell hemoglobin $(\mathrm{MCH})$ and mean corpuscular hemoglobin concentration (MCHC) were determined using an automatic analyzer (System H1, Bayer Diagnostics). The serum was analyzed for total protein, total cholesterol, HDL cholesterol, creatinine, urea, triglycerides, glucose, and alanine transaminase (ALT)/aspartate aminotransferase (AST) activities using specific commercial diagnostic kits (Fortress Diagnostics, London, UK).

\section{Histopathological analysis}

Kidney and liver samples were preserved in $10 \%$ formalin and processed by conventional techniques. Paraffin sections (5 $\mu \mathrm{m}$ thick) were stained with hematoxylin and eosin before microscopic examination.

\section{Statistical analysis}

Data are presented as mean $\pm \mathrm{SD}$. One-way ANOVA with Newman-Keuls Multiple Comparison Test was performed to assess differences between groups (16.0 SPSS Windows software). Values of $p<0.05$ were considered statistically significant.

\section{RESULTS}

\section{Acute oral toxicity}

No adverse reactions or mortality were observed at 1000 and $2000 \mathrm{mg} / \mathrm{kg}$ oral administration of ethanol extract $\left(\mathrm{LD}_{50}>2000 \mathrm{mg} / \mathrm{kg}\right)$. No significant differences in body weight 
and rectal temperature (Figure 1) of the animals were observed

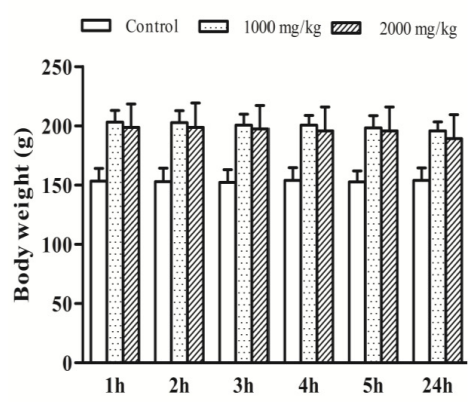

(a)

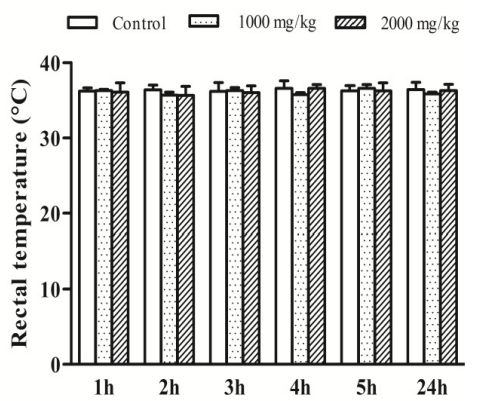

(c) between control and test groups during the experiment.

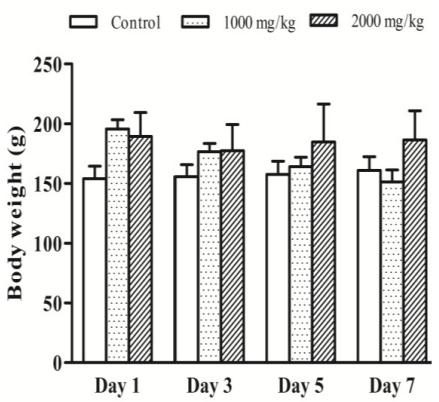

(b)

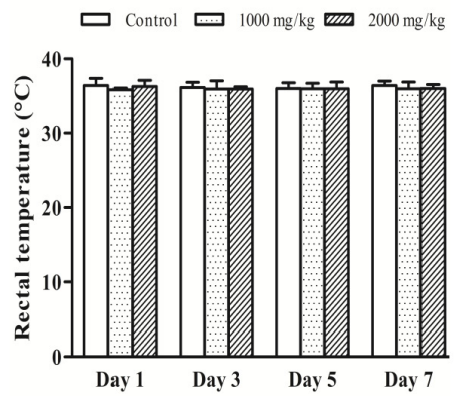

(d)

Fig. 1: Body weight ( $\mathrm{a}$ and $\mathrm{b}$ ) and rectal temperature ( $\mathrm{c}$ and $\mathrm{d}$ ) of experimental animals after oral administration of a single dose of the DABE. Each bar represents the data expressed as mean $\pm \mathrm{SD}$ for each group of rats, $n=6$.

\section{Sub-chronic oral toxicity}

Food-water consumptions, rectal temperature, and body weight evolution

EtOHDA administered daily for 28 days induced a significant increase in food consumption into the test groups (Figure 2a) throughout the treatment. Water consumption increased significantly during $3^{\text {rd }}$ week (Figure 2b). During 90 days of treatment, food consumption decreased significantly in the $8^{\text {th }}$ week, remained stable and not significant with respect to the control group (Figure 2c). No significant differences in water consumption were observed between the groups of rats (Figure $2 \mathrm{~d})$. The increase in food consumption resulted in a very marked gain in body weight of the animals which received the plant extract for 28 days (Figure 3b). This effect is significantly greater as the dose increases. However, there was no significant increase in body weight for 90 days between the groups (Figure 3d). The rectal temperature of the animals did not significantly vary during the 28 and 90 days of treatment (Figures $3 \mathrm{e}$ and $3 \mathrm{f}$ ). Changes such as sedation, defecation and salivation were observed in animals from the groups treated with 500 and $1000 \mathrm{mg} / \mathrm{kg}$ of DABE. These changes decreased with time.

\section{Relative organ weights}

No significant changes in weight of the organs (liver, kidney, heart, and spleen) were observed between the treated as compared to the control rats after oral administration of DABE over 28 and 90 days (Table 1).

Table 1: Relative organ weights $(\mathrm{g} / 100 \mathrm{~g}$ bw) recorded at the end of the study from experimental animals after 28 days and 90 days of oral administration of the DABE.

\begin{tabular}{|c|c|c|c|c|c|}
\hline \multirow{2}{*}{ Treatment } & \multirow{2}{*}{ Dose (mg/kg) } & \multicolumn{4}{|c|}{ Organ weights (g) } \\
\hline & & Kidney & Liver & Heart & Spleen \\
\hline \multirow{3}{*}{28 days } & 0 & $0.83 \pm 0.16$ & $3.23 \pm 0.63$ & $0.48 \pm 0.10$ & $0.45 \pm 0.14$ \\
\hline & 250 & $0.83 \pm 0.07$ & $3.48 \pm 0.14$ & $0.44 \pm 0.03$ & $0.50 \pm 0.05$ \\
\hline & 500 & $0.90 \pm 0.09$ & $3.74 \pm 0.38$ & $0.48 \pm 0.03$ & $0.53 \pm 0.06$ \\
\hline \multirow{5}{*}{90 days } & 1000 & $0.90 \pm 0.08$ & $3.73 \pm 0.26$ & $0.51 \pm 0.05$ & $0.57 \pm 0.11$ \\
\hline & 0 & $0.97 \pm 0.04$ & $3.73 \pm 0.13$ & $0.47 \pm 0.02$ & $0.51 \pm 0.03$ \\
\hline & 25 & $0.90 \pm 0.05$ & $3.72 \pm 0.25$ & $0.47 \pm 0.02$ & $0.48 \pm 0.05$ \\
\hline & 500 & $0.92 \pm 0.08$ & $3.64 \pm 0.17$ & $0.49 \pm 0.03$ & $0.52 \pm 0.04$ \\
\hline & 1000 & $0.91 \pm 0.06$ & $3.87 \pm 0.37$ & $0.45 \pm 0.05$ & $0.54 \pm 0.03$ \\
\hline
\end{tabular}

Data are expressed as mean $\pm \mathrm{SD}, n=6$. No statistically significant difference was observed between test and control groups. 
Table 2: Biochemical parameters in experimental animals after 28 days and 90 days of the DABE administration.

\begin{tabular}{|c|c|c|c|c|c|c|c|c|}
\hline \multirow{2}{*}{ Parameters } & \multicolumn{4}{|c|}{28 days } & \multicolumn{4}{|c|}{90 days } \\
\hline & Control & $250 \mathrm{mg} / \mathrm{kg}$ & $500 \mathrm{mg} / \mathrm{kg}$ & $1000 \mathrm{mg} / \mathrm{kg}$ & Control & $250 \mathrm{mg} / \mathrm{kg}$ & $500 \mathrm{mg} / \mathrm{kg}$ & $1000 \mathrm{mg} / \mathrm{kg}$ \\
\hline $\mathrm{CHOL}(\mathrm{mg} / \mathrm{dl})$ & $43.16 \pm 5.00$ & $51.31 \pm 8.64$ & $54.67 \pm 8.85$ & $57.43 \pm 10.08^{*}$ & $44.96 \pm 7.00$ & $51.91 \pm 7.01$ & $56.95 \pm 8.29$ & $58.87 \pm 9.59^{*}$ \\
\hline HDL CHOL (mg/dl) & $16.15 \pm 4.12$ & $16.48 \pm 1.75$ & $18.11 \pm 3.40$ & $16.90 \pm 1.89$ & $15.07 \pm 1.42$ & $21.38 \pm 3.83$ & $22.34 \pm 6.30$ & $23.75 \pm 5.90^{*}$ \\
\hline LDL CHOL (mg/dl) & $13.26 \pm 2.73$ & $19.22 \pm 6.62$ & $18.11 \pm 6.03$ & $22.94 \pm 8.64$ & $19.03 \pm 2.11$ & $20.13 \pm 5.44$ & $25.19 \pm 4.38$ & $20.85 \pm 3.73$ \\
\hline TGY (mg/dl) & $68.75 \pm 10.09$ & $78.02 \pm 11.54$ & $79.22 \pm 12.38$ & $87.89 \pm 7.01 *$ & $54.26 \pm 5.63$ & $52.01 \pm 5.92$ & $47.08 \pm 6.42$ & $71.30 \pm 9.47 * *$ \\
\hline $\operatorname{ALT}(\mathrm{U} / \mathrm{L})$ & $17.12 \pm 1.73$ & $20.66 \pm 3.73$ & $17.49 \pm 1.62$ & $20.90 \pm 1.98$ & $12.00 \pm 2.36$ & $13.22 \pm 1.60$ & $15.27 \pm 2.03^{*}$ & $17.88 \pm 1.44 * * *$ \\
\hline AST (U/L) & $37.60 \pm 3.32$ & $30.74 \pm 3.13$ & $33.62 \pm 6.98$ & $32.24 \pm 7.53$ & $37.15 \pm 4.91$ & $39.12 \pm 5.30$ & $47.07 \pm 4.71 * *$ & $55.82 \pm 3.50 * * *$ \\
\hline $\mathrm{TP}(\mathrm{g} / \mathrm{l})$ & $71.70 \pm 8.39$ & $72.43 \pm 4.93$ & $74.21 \pm 2.56$ & $74.04 \pm 4.79$ & $67.63 \pm 5.86$ & $66.44 \pm 2.51$ & $65.95 \pm 5.80$ & $64.42 \pm 1.91$ \\
\hline $\operatorname{ALB}(g / 1)$ & $19.11 \pm 2.73$ & $25.58 \pm 5.74$ & $25.05 \pm 6.44$ & $20.97 \pm 4.36$ & $26.31 \pm 2.73$ & $23.41 \pm 3.90$ & $21.51 \pm 4.40$ & $18.47 \pm 2.05^{* *}$ \\
\hline GLU (mg/dl) & $120.29 \pm 23.85$ & $129.43 \pm 17.61$ & $136.15 \pm 24.97$ & $153.36 \pm 38.07$ & $145.69 \pm 17.41$ & $231.58 \pm 25.06 * * *$ & $209.54 \pm 16.62 * * *$ & $207.79 \pm 19.65 * * *$ \\
\hline CRE $(\mu \mathrm{mol} / 1)$ & $69.77 \pm 11.74$ & $64.67 \pm 5.27$ & $66.94 \pm 14.54$ & $68.07 \pm 13.78$ & $78.28 \pm 7.76$ & $78.85 \pm 18.81$ & $76.58 \pm 5.59$ & $77.15 \pm 6.69$ \\
\hline UR (mg/dl) & $35.00 \pm 8.46$ & $34.75 \pm 7.32$ & $33.97 \pm 3.28$ & $34.97 \pm 3.09$ & $58.88 \pm 6.35$ & $45.02 \pm 5.16^{* *}$ & $45.16 \pm 4.75^{* *}$ & $40.03 \pm 4.77^{* * *}$ \\
\hline
\end{tabular}

CHOL: Total cholesterol, HDL CHOL: HDL cholesterol, LDL CHOL: LDL cholesterol, TGY: Triglycerides, ALT: Alanine transaminase, AST: Aspartate transaminase, TP: Total Protein, ALB: Albumin, GLU: Glucose, CRE: Creatinine, UR: Urea. Data are expressed as mean $\pm \mathrm{SD}, n=6 . *$, **, *** indicate a significant difference at $p$ $<0.05, p<0.01$ and $p<0.001$ respectively, compared to the appropriate control group (Newman-Keuls).

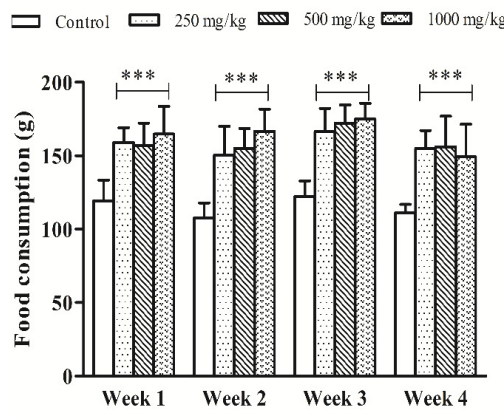

(a)

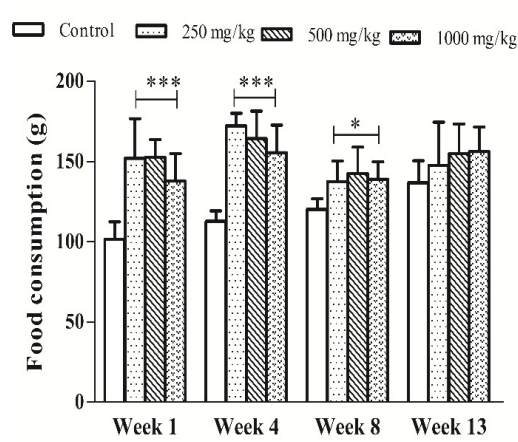

(c)

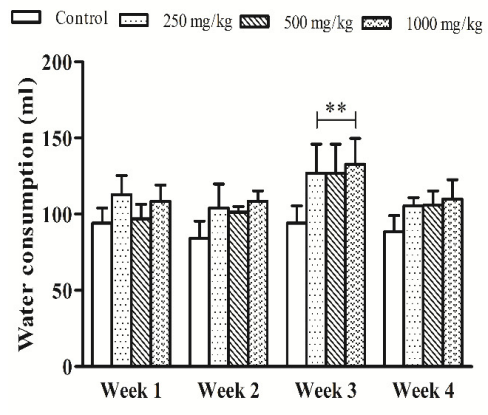

(b)

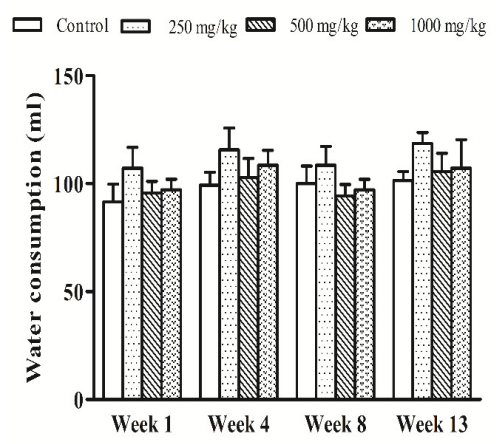

(d)

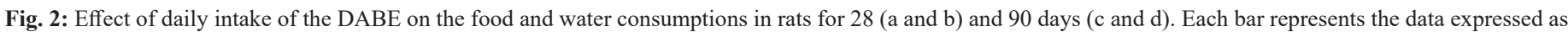

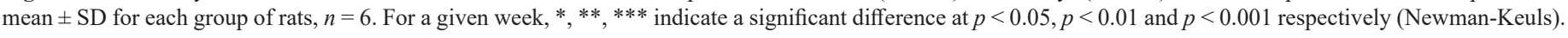

\section{Hematological and biochemical parameters}

The effects of administration of DABE after 28 and 90 days on plasma biochemical parameters in experimental rats are presented in Table 2. Except for total cholesterol and triglycerides, there were no significant differences in all the other biochemical parameters evaluated between the groups after 28 days of administration. Total cholesterol and triglycerides levels significantly increased $(p<0.05)$ only at the dose of $1000 \mathrm{mg} /$ $\mathrm{kg}$ bw. After 90 days of administration, we observed a significant increase in ALT, AST (500 and $1000 \mathrm{mg} / \mathrm{kg}$ bw, $p<0.001$ ), 
albumin $(1000 \mathrm{mg} / \mathrm{kg}$ bw, $p<0.01)$, total cholesterol, HDL cholesterol, triglycerides $(p<0.05)$ and glucose levels (all the doses, $p<0.001)$ compared to the control. We also observed a significant decrease in urea level $(p<0.05)$ of the animals which received different doses of plant extract. No significant difference was detected on hematological parameters between test and control groups (Table 3).

\section{Liver and kidney histopathology}

Histopathological analysis of liver and kidney did not show morphological alteration for 28 days (Figure 4). However, daily administration of DABE had significant effects on the hepatic tissues of the treated rats for 90 days (Figure 5). The histological study of liver showed vascular congestion and leukocyte infiltration at the doses of 500 and $1000 \mathrm{mg} / \mathrm{kg}$ bw.

Table 3: Hematological parameters in experimental animals after 28 days and 90 days of the DABE administration.

\begin{tabular}{|c|c|c|c|c|c|c|c|c|c|}
\hline Treatment & Dose (mg/kg) & WBC $\left(10^{3} / \mathrm{mm}^{3}\right)$ & $\operatorname{RBC}\left(10^{6} / \mathrm{mm}^{3}\right)$ & HGB (g/dl) & HCT (\%) & $\operatorname{MCV}\left(\mu \mathrm{m}^{3}\right)$ & MCH (pg) & $\operatorname{MCHC~(g/dl)~}$ & PLT $\left(10^{3} / \mathrm{mm}^{3}\right)$ \\
\hline \multirow{5}{*}{28 days } & 0 & $5.83 \pm 0.99$ & $7.02 \pm 0.73$ & $12.15 \pm 0.78$ & $32.61 \pm 5.45$ & $46.45 \pm 7.33$ & $17.30 \pm 1.92$ & $37.25 \pm 5.18$ & $310.50 \pm 10.32$ \\
\hline & 250 & $5.40 \pm 0.45$ & $6.69 \pm 0.27$ & $13.03 \pm 0.89$ & $39.80 \pm 4.40$ & $59.49 \pm 7.44$ & $19.47 \pm 1.44$ & $32.73 \pm 4.86$ & $315.50 \pm 12.04$ \\
\hline & 500 & $5.23 \pm 0.37$ & $6.33 \pm 0.62$ & $12.58 \pm 0.67$ & $37.75 \pm 3.51$ & $59.63 \pm 10.34$ & $19.87 \pm 2.91$ & $33.32 \pm 3.10$ & $320.16 \pm 8.19$ \\
\hline & 1000 & $5.86 \pm 0.46$ & $6.27 \pm 0.08$ & $12.70 \pm 0.89$ & $37.58 \pm 3.94$ & $56.93 \pm 7.48$ & $20.25 \pm 1.77$ & $33.79 \pm 1.87$ & $318.33 \pm 11.50$ \\
\hline & 0 & $18.25 \pm 2.48$ & $7.04 \pm 0.74$ & $13.28 \pm 0.99$ & $40.21 \pm 2.91$ & $56.83 \pm 1.06$ & $19.03 \pm 0.71$ & $33.46 \pm 1.66$ & $423.50 \pm 56.04$ \\
\hline \multirow{3}{*}{90 days } & 250 & $21.58 \pm 2.52$ & $7.38 \pm 0.44$ & $13.71 \pm 0.98$ & $43.05 \pm 2.38$ & $58.16 \pm 0.68$ & $18.63 \pm 1.78$ & $31.93 \pm 2.78$ & $438.66 \pm 49.31$ \\
\hline & 500 & $19.90 \pm 3.38$ & $7.94 \pm 0.42$ & $12.01 \pm 0.94$ & $36.23 \pm 2.55$ & $61.16 \pm 5.70$ & $20.61 \pm 3.38$ & $33.51 \pm 3.51$ & $443.16 \pm 21.73$ \\
\hline & 1000 & $17.53 \pm 2.01$ & $7.24 \pm 0.62$ & $13.83 \pm 1.12$ & $40.98 \pm 3.66$ & $56.50 \pm 2.34$ & $19.11 \pm 0.76$ & $33.83 \pm 1.80$ & $357.66 \pm 19.59$ \\
\hline
\end{tabular}

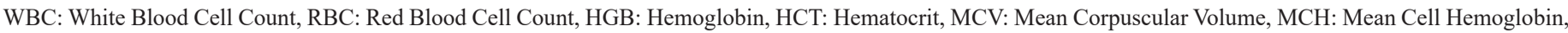

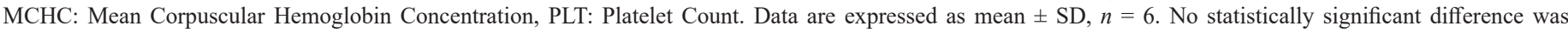
observed between test and control groups.

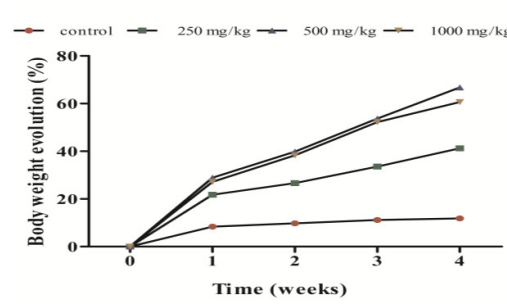

(a)

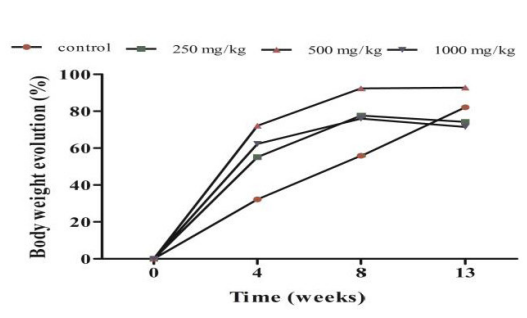

(c)

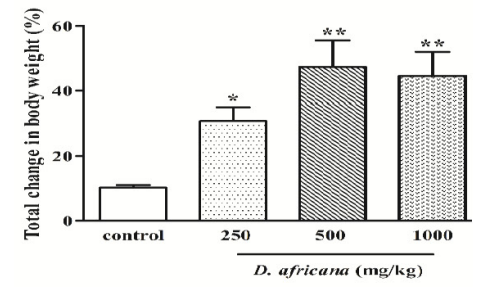

(b)

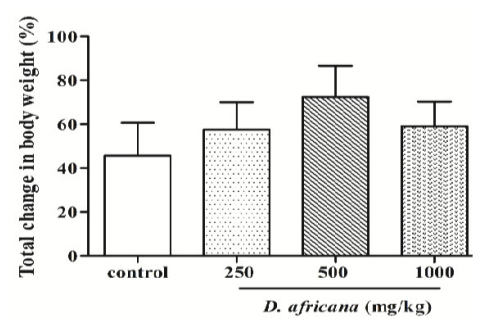

(d)

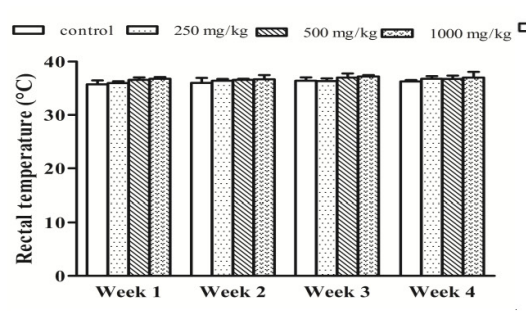

(e)

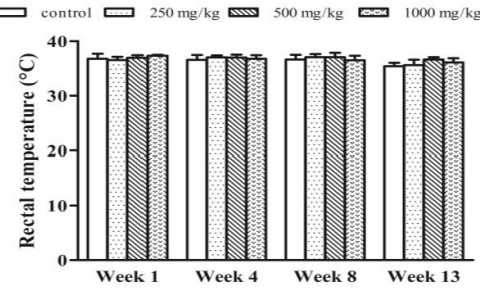

(f)

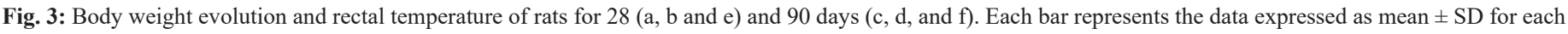
group of rats, $n=6$. For a given dose, $* * *$ indicate a significant difference at $p<0.05$ and $p<0.01$ respectively (Newman-Keuls). 


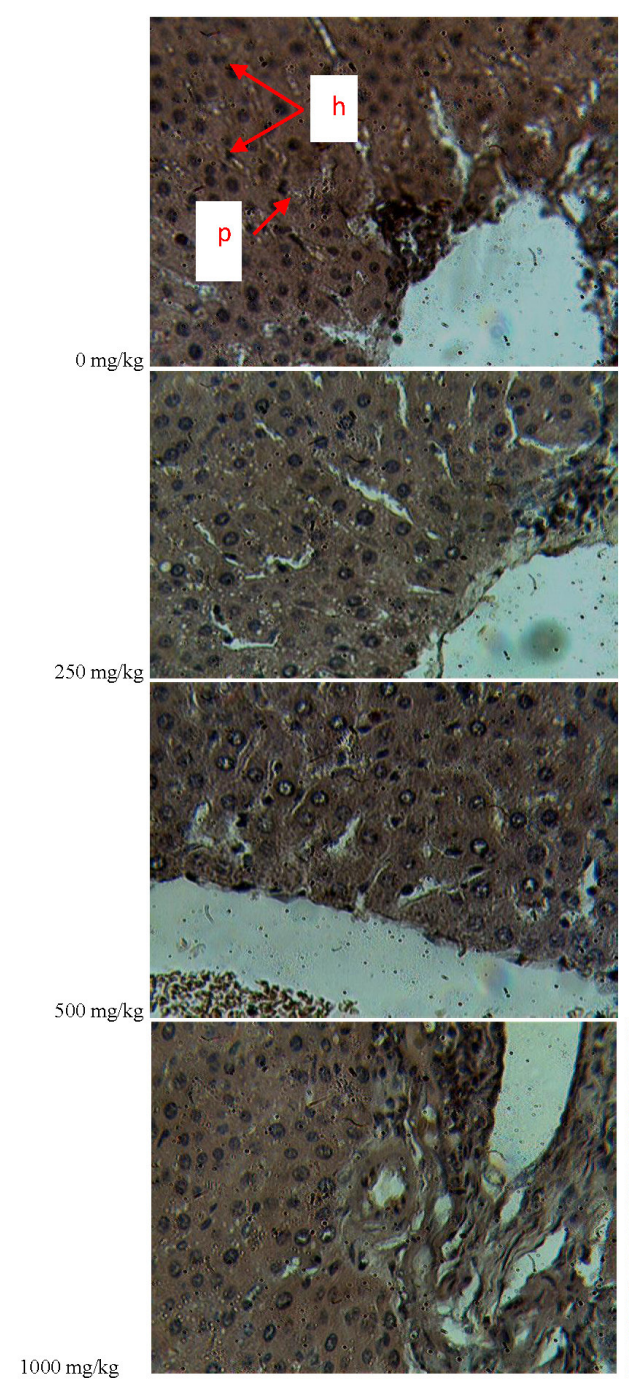

(a)

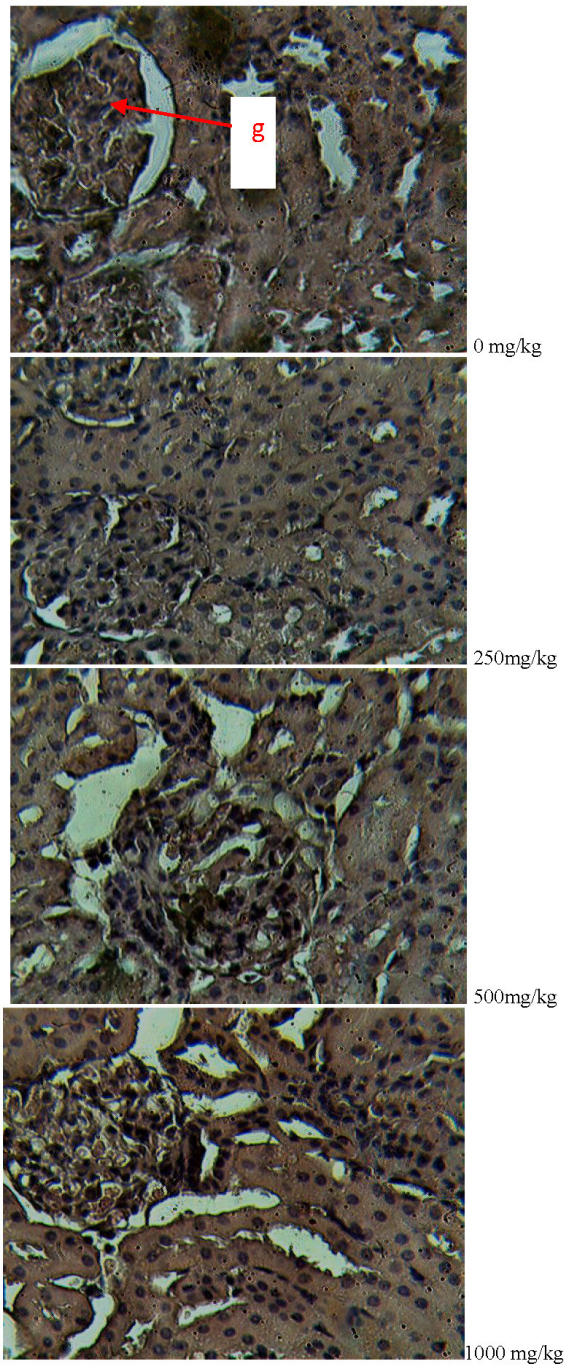

(b)

Fig. 4: Histology of the liver (a) and kidney (b) of the control rats and those exposed to various doses of DABE for 28 days. Histological analysis of the liver and kidney of the control rats show normal structure: Hepatocyte (h), parenchyma (p) and glomerula (g) respectively. H \& E 400×.

\section{DISCUSSION}

Often mistakenly considered as safe because they are natural, phytotherapeutic products have bioactive compounds that are likely to cause adverse effects. In addition, the pharmacovigilance services in this area are insufficient. Thus, the determination of the frequency of the secondary effects related to their use becomes difficult. Thereby, all the natural products used in therapeutics must beforehand be submitted to efficacy and safety tests (Tang et al., 2017). In the acute oral toxicity study, no adverse reactions or mortality were observed at 1000 and 2000 $\mathrm{mg} / \mathrm{kg}$ oral administration of extract, thus the $\mathrm{LD}_{50}$ of DABE can be estimated to be above $2000 \mathrm{mg} / \mathrm{kg}$. This strongly suggests that $\mathrm{DABE}$ is relatively non-toxic since substances with an $\mathrm{LD}_{50}$ value of $1000 \mathrm{mg} / \mathrm{kg}$ by the oral route are regarded as being safe or of low toxicity (OECD, 2001; Obici et al., 2008). In addition, body weight and rectal temperature of the animals did not change. Several studies showed that species of the Melastomataceae family are non-toxic even at $5000 \mathrm{mg} / \mathrm{kg}$ (Zakaria et al., 2006;
Sunilson et al., 2009; Alnajar et al., 2012). Final and daily clinical observations in repeated dose studies are of the major importance (Feres et al., 2006). Food consumption increased significantly in the groups treated with the extract for 28 days. This suggests that the extract will stimulate appetite. However, it decreased significantly from the eighth week for 90 days of treatment. This decrease indicates that the extract could be toxic beyond the $8^{\text {th }}$ week of treatment. At high doses or long periods of administration, some chemical constituents of the crude plant extract can be metabolized into toxic end-products, which may interfere with the efficiency of gastric function (Choksi, 2007). There were no significant changes in water consumption of animals. An increase in the body weight of the test groups was observed relative to the control group for 28 days of treatment. A significant increase in food consumption could be responsible for the observed gain in body weight. However, adipose tissue is a dynamic organ that plays an important role in energy balance and mass changes depending on the metabolic needs of the 


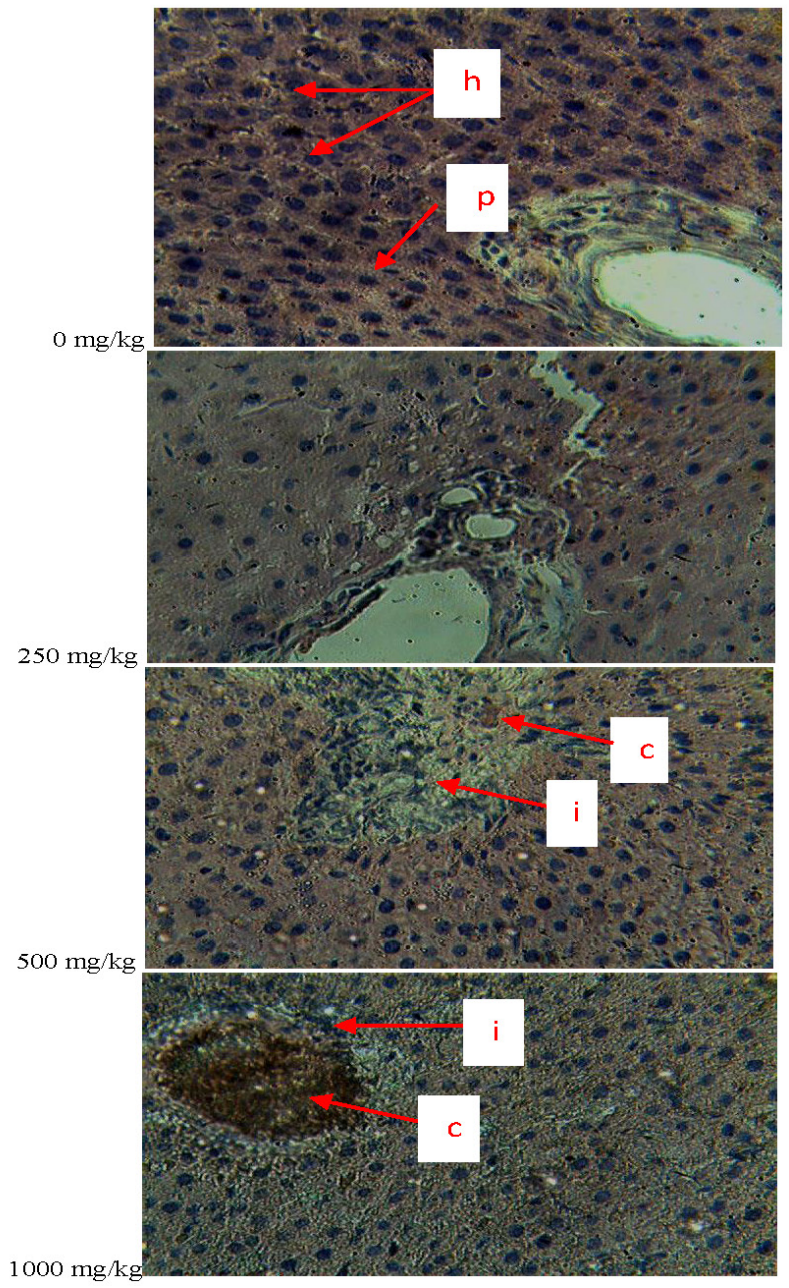

(a)

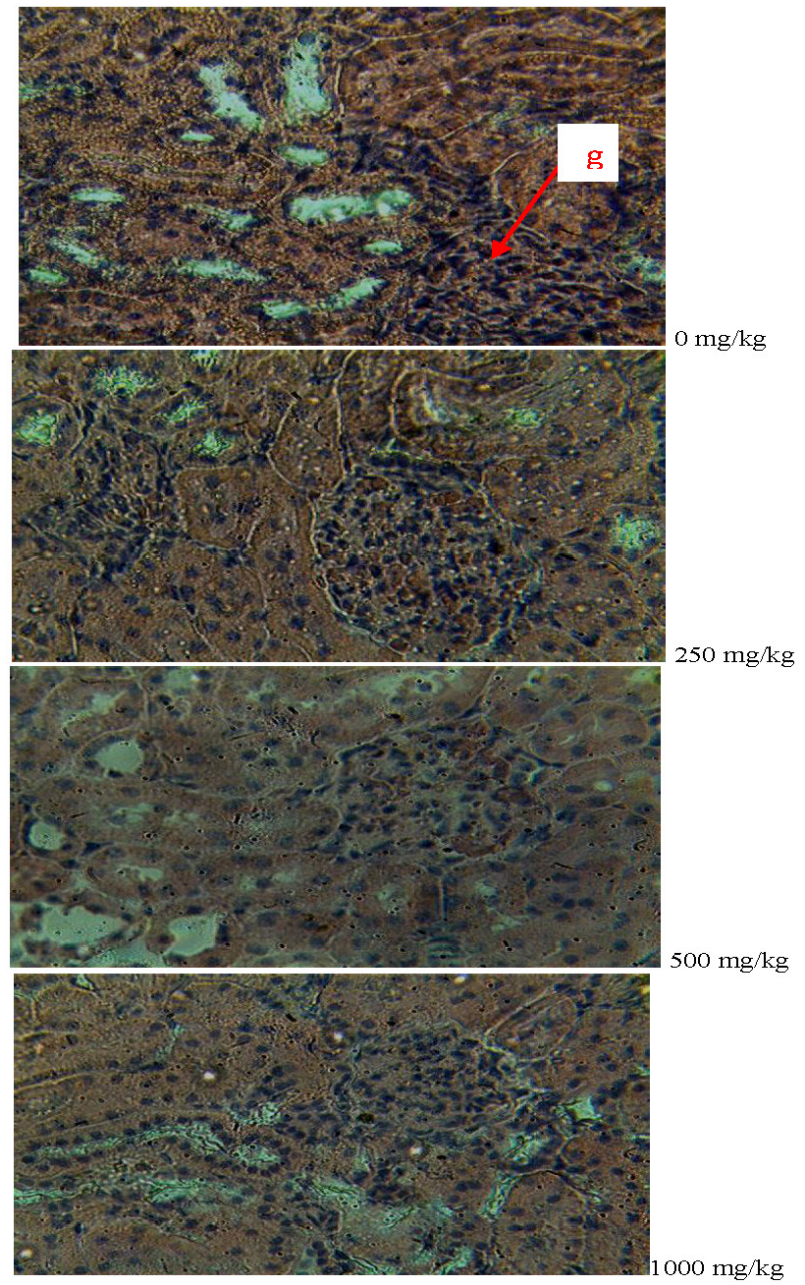

(b)

Fig. 5: Histology of the liver (a) and kidney (b) of the control rats and those exposed to various doses of DABE for 90 days. Vascular congestions (c) and inflammation sites (i) are present in the liver at the doses of 500 and $1000 \mathrm{mg} / \mathrm{kg}$. Histological analysis of the liver and kidney of the control rats show normal structure: hepatocyte (h), parenchyma (p) and glomerula (g) respectively. H \& E 400×.

body (Lafontan and Langin, 2009). It has been reported that the imbalance between intake and energy expenditure results from the abnormal excess growth of white adipose tissue, which can lead to overweight (obesity) (Jo et al., 2009; Lim et al., 2013). Further studies are needed to confirm the ability of $D$. africana to induce obesity. There was a non-significant increase in the body weight of the animals in the test groups relative to the control group during 90 days of treatment. However, a decrease in the body weight of the animals in the test groups was observed from the eighth week onwards. This would be due to the significant decrease in food consumption observed from the $8^{\text {th }}$ week, which would reflect a loss of appetite resulting from the interference of the extract with the metabolism of carbohydrates, proteins or lipids (Klaasen and Casarett, 2001). The increase in the body weight of the animals had no effect on the weight of their organ. We observed normal values of all parameters analysed in experimental rats when compared to the control, indicating that DABE had no observed adverse effect on the hematopoietic system. This serves as an important index of the physiological and pathological status (Guyton and Hall, 2006). Renal changes are likely to occur in preclinical toxicity studies because of the high doses administered and the fact that the kidneys eliminate many drugs and their metabolites. Analysis of liver markers revealed that prolonged use (90 days) of DABE had adverse effects on liver function. We observed a significant increase in serum levels of ALT and ASAT at doses of 500 and $1000 \mathrm{mg} / \mathrm{kg}$ bw. This suggests that, at these doses, the extract would affect hepatic function at the high doses during prolonged intake. This was reflected in the histopathological examination of liver, which found vascular congestion and leukocyte infiltration in groups of animals receiving these doses of extract. Significant reduction in serum level of albumin at a dose of $1000 \mathrm{mg} / \mathrm{kg}$ would result in hepatic or renal dysfunction (Upur et al., 2009). Prolonged administration of the extract for 90 days also caused a significant decrease in serum urea level of the markers of renal function. On the other hand, the creatinine level did not change, which would result in liver failure. Therefore, DABE had no 
adverse effect on renal function. Some factors associated with arteriosclerosis and cardiovascular diseases are the levels of lipids and lipoproteins in the blood (Wang et al., 2010). The significant increase in total cholesterol and triglyceride levels after treatment with extract at the dose of $1000 \mathrm{mg} / \mathrm{kg}$ b.w presents a high risk of hypercholesterolemia and hypertriglyceridemia. This is related to a significant increase in the observed glucose level. This may be due to altered insulin activity or insufficient secretion caused by the ethanol extract, causing hyperglycemia and consequently activating hormone-sensitive lipases in the adipose to release lipids (Gauvreau et al., 2011). This is also reflected in the significant increase in body weight of the animals (Changhyun and Uhee, 2012). D. africana presented a hyperglycemic effect confirm by the vascular and inflammatory changes observed in treated groups that could be due to the laying of fat droplets in those tissues.

\section{CONCLUSION}

This study provides information on the toxicological profile of DABE. The results obtained suggest that DABE is relatively non-toxic in daily oral administration for a period of 28 days. However, it becomes toxic for 90 days at the doses of 500 and $1000 \mathrm{mg} / \mathrm{kg}$ bw. These uphold indigenous knowledge on its safe folkloric use in humans and provide justification for specifically designed studies to investigate other beneficial pharmacological effects and clinical studies in humans.

\section{ABBREVIATIONS}

DABE: ethanol stem bark extract of Dichaetanthera africana; bw: Body weight; $\mathrm{LD}_{50}$ : Lethal dose; EDTA: Ethylene diamine tetraacetic acid; WBC: White blood cell counts; RBC: red blood cell counts; PLT: platelet counts; HCT: hematocrit; HGB: hemoglobin; MCV: mean corpuscular volume; $\mathrm{MCH}$ : mean cell hemoglobin; MCHC: mean corpuscular hemoglobin concentration; ALT: alanine transaminase; AST: aspartate aminotransferase.

\section{CONFLICT OF INTEREST}

The authors declare that they have no conflict of interests.

\section{AUTHORS' CONTRIBUTIONS}

RANN, ASM, and RSP designated the study and supervised the work. CEG co-supervised the work. ALMK, LRYT, and ADT work in the laboratory to carry out the experiments. ATT prepared the plant extract. GAA, RMEE, DNNN, PVTF, and RSM helped in preparing the manuscript. All authors read and approved the final manuscript.

\section{ACKNOWLEDGMENTS}

We are grateful to Institute of Medical Research and Medicinal Plant Studies (IMPM), Yaoundé, for providing facility and technical assistance.

\section{REFERENCES}

Akoue GN, Obame LC, Ondo JP, Brama I, N'nang ESO, Tapoyo SY, Souza A. Phytochemical composition and antiradical activity of Sakersia africana Hook. f. medicinal plant from Gabon. International Journal of Biomolecules and Biomedicine, 2013; 3:1-8.

Alnajar ZAA, Abdulla MA, Ali HM, Alshawsh MA, Hadi AHA Acute toxicity evaluation, antibacterial, antioxidant and immunomodulatory effects of Melastoma malabathricum. Molecules, 2012; 17:3547-3559.
Burkill HM. 1997. The useful plants of tropical West Africa. $3^{\text {rd }}$ ed. London: Royal Botanic Gardens Kew 981.

Changhyun R, Uhee J. Screening of crude plant extracts with anti-obesity activity. International Journal of Molecular Sciences, 2012; 13:1710-1719.

Chokshi D. Subchronic oral toxicity of a standardized white kidney bean (Phaseolus vulgaris) extract in rats. Food and Chemical Toxicology, 2007; 45:32-40.

Etame RME, Mouokeu RS, Ngono NRA, Assam AJP, Masoohe AM, Tientcheu R, Hopogap ML, Etoa FX. Acute and sub-acute toxicity of Harungana madagascariensis LAM (Hypericaceae) stem bark methanol extract. Journal of Applied Pharmaceutical Science, 2017; 7:160-167.

Feres CA, Madalosso RC, Rocha OA, Leite JP, Guimaraes TM, Toledo VP, Tagliati CA. Acute and chronic toxicological studies of Dimorphandra mollis in experimental animals. Journal of Ethnopharmacology, 2006; 108:450-456.

Fonge BA, Egbe EA, Fongod AGN, Focho DA, Tchetcha DJ, Nkembi L, Tacham WN. Ethnobotany survey and uses of plants in the Lewoh-Lebang communities in the Lebialem highlands, south west region, Cameroon. Journal of Medicinal Plants Research, 2012; 6:855-865.

Gandolfo GM, Girelli G, Conti L. Hemolytic anaemia and thrombocytopaenia induced cyanidanol. Acta Haematologia, 1992; 88:9699.

Gauvreau D, Villeneuve N, Deshaies Y, Cianflone K. Novel adipokines: links between obesity and atherosclerosis. Annales d'Endocrinologie, 2011; 72:224-231.

Guyton AC, Hall JE. 2006. Textbook of medical physiology, $11^{\text {th }}$ ed. Philadelphia: Elsevier Saunders 1152.

Jo J, Gavrilova O, Pack S, Jou W, Mullen S, Sumner AE, Cushman SW, Periwal V. Hypertrophy and/or hyperplasia: dynamics of adipose tissue growth. PLoS Computational Biology, 2009; 5:324-335.

Klaassen CD, Casarett, Doull's. 2001. Toxicology: the basic science of poisons, $6^{\text {th }}$ ed. New York: McGraw-Hill Press 1229.

Lafontan M, Langin D. Lipolysis and lipid mobilization in human adipose tissue. Progress in Lipid Research, 2009; 48:275-297.

Lim DW, Kim YT, Jang YJ, Kim YE, Han D. Antiobesity effect of Artemisia capillaris extracts in high-fat diet induced obese rats. Molecules, 2013; 18:9241-9252.

Mokale KAL, Pawar SR, Ngono NRA, Pateriya P, Pal NP, Tchinda TA, Agbor AG, Etame RME, Mouokeu RS, Mouelle SQ, Gueiffier EC. Antioxidant, analgesic and antipyretic activities of ethanol extract of the stem bark Dichaetanthera africana (Hooker F.) Jacq. Felix. (Melastomataceae). British Journal of Pharmaceutical Research, 2017a; 14:1-12.

Mokale KAL, Ngono NRA, Pawar SR, Pateriya P, Pal NP, Etame RME, Tchinda TA, Agbor AG, Kumar S, Mouokeu RS, Mouelle SQ, Gueiffier EC. Anti-inflammatory activity and bioavailability profile of ethanolic extract of Dichaetanthera africana. Pharmacologia, 2017b; 8: 3240.

Musila MN, Ngai DN, Mbiri JW, Njagi SN, Mbinda WM, Ngugi MP. Acute and sub-chronic oral toxicity study of methanolic extract of Caesalpinia volkensii (Harms). Journal of Drug Metabolism \& Toxicology, 2017; 8:1-8.

Obici S, Otobone FJ, Da silva SVR, Ishida K, Da silva JC, Nakamura CV, Garcia CDA, Audi EA. Preliminary toxicity study of dichloromethane extract of Kielmeyera coriacea stems in mice and rats. Journal of Ethnopharmacology, 2008; 115:131-139.

Ochoa MGP, Reyes VHA, Sánchez AMV, Guzmán MAM, Noguera PR, Angeles E, Hurtado FA. Subchronic toxicity study in rats of two new ethyl-carbamates with ixodicidal activity. BioMed Research International, 2014. doi:10.1155/2014/467105.

Organization for Economic Co-operation and Development OECD Guidelines for testing of chemicals. Revised Draft Guidelines 425: Acute Oral Toxicity-Up and Down Method. Available at: http://www.oecdilibrary.org/docserver/download/9742501e.pdf. Adopted: $17^{\text {th }}$ December 2001. 
Organization for Economic Co-operation and Development. OECD Guidelines for the Testing of Chemicals. Assay n ${ }^{\circ}$ 408: Repeated Dose 90-day Oral Toxicity in Rodents. Available at: http://www.oecdilibrary.org/docserver/download/9740801e.pdf. Adopted: $21^{\text {st }}$ September 1998.

Organization for Economic Co-operation and Development. OCDE Guidelines for the Testing of Chemicals. Assay n ${ }^{\circ}$ 407: Repeated Dose 28-day Oral Toxicity in Rodents. Available at: http://www.oecdilibrary.org/docserver/download/9740701e.pdf. Adopted: 3 October 2008.

Pauwels L. 1993. Nzayilu N'ti: Guide des arbres et arbustes de la région de Kinshasa-Brazzaville, Belgique: Jardin Botanique National de Belgique 495.

Sunilson JAJ, Anandarajagopal K, Kumari AVG, Mohan S. Antidiarrhoeal activity of leaves of Melastoma malabathricum linn. Indian Journal of Pharmaceutical Sciences, 2009; 71: 691-695.

Tang R, Tiana RH, Caib JZ, Wua JH, Shena XL, Hua YJ. Acute and sub-chronic toxicity of Cajanus cajan leaf extracts. Pharmaceutical Biology, 2017; 55:1740-1746.

Tarkang AP, Agbor AG, Ayong SL, Okalebo AF, Guantai NA. Cytotoxicity and in vivo toxicological screening of a polyherbal product, NEFANG. World Journal of Pharmaceutical, Research, 2015; 4:82-101.

Tripathy S, Pradhan D, Anjana M. Anti-inflammatory and antiarthritic potential of Ammania baccifera Linn. International Journal of Pharma and Biosciences, 2010; 1:1-7.
Upur H, Amat N, Blazekovic B, Talip A. Protective effect of Cichorium glandulosum root extract on carbon-tetrachloride induced and galactosamine induced hepatotoxicity in mice. Food and Chemical Toxicology, 2009; 47:2022-2030.

Wang X, Zhang W, Wang Y, Peng D, Ihsan A, Huang X, Liu Z, Dai M, Zhou W, Yuan ZH. Acute and sub-chronic oral toxicological evaluations of quinocetone in Wistar rats. Regulatory Toxicology and Pharmacology, 2010; 58:421-427.

Zakaria ZA, Raden M, Nor RNS, Hana KG, Abdul GZDF, Sulaiman MR, Rathna DG, Mat JAM, Somchit MN, Fatimah CA. Antinociceptive, anti-inflammatory and antipyretic properties of Melastoma malabathricum leaves aqueous extract in experimental animals. Canadian Journal of Physiology and Pharmacology, 2006; 84:1291-1299.

\section{How to cite this article:}

Kognou ALM, Tchamgoue AD, Tchokouaha LRY, NthengeNgumbau DN, Fokou PVT, Tchinda AT, Agbor GA, Etame RME, Mouokeu RS, Gueiffier CE, Pawar RS, Mouelle AS, Ngane RAN. Acute and sub-chronic toxicity studies of Dichaetanthera africana (Hook. F.) Jacq. Fel. (Melastomataceae) stem bark ethanol extract. J App Pharm Sci, 2018; 8(06): 147-155. 